\title{
Peranan Partisipasi Masyarakat Terhadap Pembangunan Desa (Studi pada Pembangunan Irigasi di Desa Namo Bintang Kecamatan Pancur Batu)
}

\author{
Vina Ompusunggu* \\ *Dosen Fakultas Ekonomi Universitas Quality \\ email: vinaompusunggu@gmail.com
}

\begin{abstract}
Abstrak
Tujuan dari penelitian ini adalah untuk menganalisis perkembangan partisipasi masyarakat di desa Namo Bintang, Kecamatan Pancur Batu dan bagaimana pembangunan pemberdayaan masyarakat di Desa namo Bintang. Penelitian ini menggunakan data kualitatif yang bertujuan untuk mengambarkan secara detail dan dalam tentang partsipasi masyarakat dalam pembangunan masyarakat. Pengumpulan data menggunakan kuisoner dan interview sebagai data kualitatif dan beberapa dokumen. Hasil penelitian menunjukkan bahwa proses perencanaan pembangunan tidak di jalankan dengan baik di Desa Namo Bintang „, tingkat partisipasi masyarakat dalam perencanaan pembangunan masih rendah, masyarakat tidak dilibatkan dalam kegiatan sesuai dengan yang mereka butuhkan. Oleh karena itu hal ini membutuhkan pembangunan partsipasi dalam penyelesaiannya. Pemerintah seharusnya mempertimbangkan anggaran yang sesuai dengan kebutuhan masyarakat. Anggaran yang diperuntukkan untuk pembangunan masyarakat sebaiknya diberikan secara keseluruhan bukan bertahap sehingga tim pelaksana dan pekerja tidak berhenti sebelum kegiatan selesai, disamping itu dibutuhkan sosialisasi informasi yang optimal kepada masyrakat Desa Namo Bintang sehingga mereka lebih terlibat dalam proses, lebih dari pada itu rencana pembangunan memang menjadi kebutuhan masyarakatnya.
\end{abstract}

\section{Keywords: Partisipasi, Masyarakat, Pembangunan}

\begin{abstract}
This research has aims to describe and analyze society development participation in Namo Bintang Village, Pancur Batu District and to know how development in Namo Bintang Village to empower communities. This research belongs to qualitative research aiming to describe in detail and deeply about society participation in rural development. The instruments for collecting data are observation sheet and interview as the qualitative data and using the document. The results showed that planning development process has not implemented well in Namo Bintang Village, Society participation in development planning in Namo Bintang Village was still low, the communities aren 't involved to conduct the priority of the activities which is able to their need. Therefore, it needs an accomplishment in participative development. The government should consider the suitability of the budgetary budget with Rural needs. The budgetary budget for the implementation of rural development should be given as a whole without having to be gradual so that the Implementing Team and the workers do not stop before the activity is completed, other than that need optimal socialization in the provision of information to the community in Namo Bintang Village so that they are more involved in the process, more so that the development planning can become the needs of the community.
\end{abstract}

\section{Keywords: Society Participation and Rural Development}

\section{PENDAHULUAN}

$\begin{array}{crr}\text { Salah } & \text { satu penghambat } \\ \text { pembangaunan } & \text { ekonomi } & \text { adalah } \\ \text { kemiskinan. Pembangunan merupakan }\end{array}$

proses pewujudan cita-cita negara untuk mewujudkan masyarakat yang makmur dan sejahtera secara merata diseluruh wilayah Indonesia, namun demikian 
pembangunan yang menjadi dasar terwujudnya masyarakat yang makmur dan sejahtera belumlah bisa dinikmati secara merata oleh seluruh rakyat Indonesia. Ini dikarenakan adanya salah satu faktor geografis. Geografis wilayah Indonesia terdiri atas banyak pulaupulau yang terpisahkan, persebaran penduduk yang tidak merata ditambah lagi dengan akses atau infrastruktur yang tidak sama dan merata antara satu wilayah dengan wilayah lainnya.

$$
\text { Indonesia memiliki }
$$

permasalahan kemiskinan yang kompleks,sehingga dibutuhkan intervensi semua pihak secara bersama dan terkoordinasi. Ia di pengaruhi oleh beberapa faktor yang saling berkaitan antara satu dengan yang lainnya. Faktor tersebut antara lain tingkat pendapatan, pendidikan, kesehatan, akses barang dan jasa, lokasi geografis, gender dan kondisi lingkungan. Untuk menanggulangi kemiskinan dalam meningkatkan kesejahteraan masyarakat, pemerintah perlu melakukan upaya-upaya melalui pemberdayaan masyarakat terhadap pembangunan. Oleh karena itu, kemiskinan wajib untuk ditanggulangi, sebab jika tidak tertanggulangi akan dapat mengganggu pembanguan nasional.

Namo Bintang merupakan salah satu desa yang ikut serta dalam pelaksanaan pembangunan desa, dimana masyarakat nya sebagian besar hidup dari pertanian. Untuk menanggulangi kemiskinan dalam meningkatkan kesejahteraan masyarakat dibentuklah Program Peningkatan Kualitas Permukiman (P2KP) di Perkotaan. Dari latar belakang diatas terdapat beberapa maslah yang akan di teliti yaitu bagaimana peranan partisipasi masyarakat terhadap pembangunan desa studi pada pembangunan irigasi di Desa Namo Bintang Kecamatan Pancur Batu.

\section{Partisipasi Masyarakat}

Dalam kamus lengkap Bahasa Indonesia dijelaskan "partisipasi" berarti: hal turut berperan serta dalam suatu kegiatan, keikutsertaan, peran serta. Geddesian (dalam Soemarmo 2005 :26) mengemukakan bahwa pada dasarnya masyarakat dapat dilibatkan secara aktif sejak tahap awal penyusunan rencana. Keterlibatan masyarakatdapat berupa: pendidikan melalui pelatihan, (2) partisipasi aktif dalam pengumpulan informasi, (3) partisipasi dalam memberikan alternatif rencana dan usulan kepada pemerintah.

Menurut Juliantara (2002:87) substansi dari partisipasi adalah bekerjanya suatu sistem pemerintahan dimana tidak ada kebijakan yang diambil tanpa adanya persetujuan dari rakyat, sedangkan arah dasar yang akan dikembangkan adalah proses pemberdayaan, lebih lanjut dikatakan bahwa tujuan pengembangan partisipasi adalah: Pertama, bahwa partisipasi akan memungkinkan rakyat secara mandiri (otonom) mengorganisasi diri, dan dengan demikian akan

memudahkan masyarakat menghadapi situasi yang sulit, serta mampu menolak berbagai kecenderungan yang merugikan. Kedua, suatu partisipasi tidak hanya menjadi cermin konkrit peluang ekspresi aspirasi dan jalan memperjuangkannya, tetapi yang lebih penting lagi bahwa partisipasi menjadi semacam garansi bagi tidak diabaikannya kepentingan masyarakat. Ketiga, bahwa persoalan-persoalan dalam dinamika pembangunan akan dapat diatasi dengan adanya partisipasi masyarakat. (Juliantara, 2002: 89-90).

Pandangan lainnya, sebagaimana dinyatakan oleh Mubyarto (1984:35), "partisipasi masyarakat dalam pembangunan pedesaan harus diartikan 
sebagai kesediaan untuk membantu berhasilnya setiap program sesuai kemampuan setiap orang tanpa berarti mengorban kepentingan diri sendiri". Selanjutnya disebutkan pula bahwa dalam keadaan yang paling ideal keikutsertaan masyarakat merupakan ukuran tingkat partisipasi rakyat. Semakin besar kemampuan mereka untuk menentukan nasibnya sendiri, maka semakin besar pula kemampuan mereka dalam pembangunan.

Bintoro menyatakan bahwa guna mencapai keberhasilan pembangunan maka partisipasi

masyarakat dalam pembangunan sangat penting, yang dapat dilaksanakan dalambkegiatan berikut:

Keterlibatan dalam penentuan arah, kinerja dan kebijakan pembangunan yang dilakukan pemerintah;

Keterlibatan dalam pelaksanaan kegiatan pembangunan, yang termasuk di dalamnya adalah memikul beban dan tanggung jawab pembangunan, yang dapat dilakukan dengan sumbangan memobilisasi pembiayaan pembangunan, melakukan kegiatan produktif, mengawasi jalannya pembangunan dan lain-lain; (3) Keterlibatan dalam menerima hasil dan manfaat pembangunan secara adil.

\section{Masyarakat Desa}

Yang dimaksud dengan desa menurut Sutardjo Kartodikusuma mengemukakan sebagai berikut: Desa adalah suatu kesatuan hukum dimana bertempat tinggal suatu masyarakat pemerintahan tersendiri. Menurut Bintaro, desa merupakan perwujudan atau kesatuan goegrafi, sosial, ekonomi, politik dan kultur yang terdapat ditempat itu (suatu daerah), dalam hubungan dan pengaruhnya secara timbal balik dengan daerah lain. Sedang menurut Paul H. Landis :Desa adalah pendudunya kurang dari 2.500 jiwa. Dengan ciri ciri sebagai berikut : a) Mempunyai pergaulan hidup yang saling kenal mengenal antara ribuan jiwa.

b) Ada pertalian perasaan yang sama tentang kesukaan terhadap kebiasaan

c) Cara berusaha (ekonomi) adalah agraris yang paling umum yang sangat dipengaruhi alam seperti : iklim, keadaan alam ,kekayaan alam, sedangkan pekerjaan yang bukan agraris adalah bersifat sambilan

Dalam UU Nomor 32 Tahun 2004 disebutkan pengertian desa sebagai kesatuan masyarakat hukum yang memiliki batas wilayah, yang berwenang untuk mengatur dan mengurus kepentingan masyarakat setempat, berdasarkan asal-usul dan adat istiadat setempat yang diakui dan dihormati dalam system pemerintahan Negara Kesatuan Republik Indonesia.

Dalam buku Sosiologi karangan Ruman Sumadilaga seorang ahli Sosiologi "Talcot Parsons" menggambarkan masyarakat desa sebagai masyarakat tradisional (Gemeinschaft) yang mebngenal ciri-ciri sebagai berikut :

a) Afektifitas ada hubungannya dengan perasaan kasih sayang, cinta , kesetiaan dan kemesraan. Perwujudannya dalam sikap dan perbuatan tolong menolong, menyatakan simpati terhadap musibah yang diderita orang lain dan menolongnya tanpa pamrih.

b) Orientasi kolektif sifat ini merupakan konsekuensi dari Afektifitas, yaitu mereka mementingkan kebersamaan, tidak suka menonjolkan diri, tidak suka akan orang yang berbeda pendapat, intinya semua harus memperlihatkan keseragaman persamaan.

c) Partikularisme pada dasarnya adalah semua hal yang ada hubungannya dengan keberlakuan khusus untuk suatu tempat atau daerah tertentu. Perasaan subyektif, perasaan 
kebersamaan sesungguhnya yang hanya berlaku untuk kelompok tertentu saja.(lawannya universalisme)

d) Askripsi yaitu berhubungan dengan mutu atau sifat khusus yang tidak diperoleh berdasarkan suatu usaha yang tidak disengaja, tetapi merupakan suatu keadaan yang sudah merupakan kebiasaan atau keturunan.(lawanya prestasi).

e) Kekabaran (diffuseness).Sesuatu yang tidak jelas terutama dalam

\begin{tabular}{|l|l|}
\hline \multicolumn{1}{|c|}{ Masyarakat Pedesaan } & \multicolumn{1}{c|}{ Masyarakat Perkotaan } \\
\hline Perilaku homogeny & Perilaku heterogen \\
\hline $\begin{array}{l}\text { Perilaku yang dilandasi oleh konsep } \\
\text { kekeluargaan dan kebersamaan }\end{array}$ & $\begin{array}{l}\text { Perilaku yang dilandasi oleh konsep } \\
\text { pengandalan diri dan kelembagaan }\end{array}$ \\
\hline $\begin{array}{l}\text { Perilaku yang berorientasi pada tradisi } \\
\text { dan status }\end{array}$ & $\begin{array}{l}\text { Perilaku yang berorientasi pada } \\
\text { rasionalitas dan fungsi }\end{array}$ \\
\hline Isolasi sosial, sehingga static & Mobilitas sosial, sehingga dinamik \\
\hline Kesatuan dan keutuhan kultural & Kebauran dan diversifikasi cultural \\
\hline Banyak ritual dan nilai-nilai sacral & Birokrasi fungsional dan nilai-nilai sekular \\
\hline Kolektivisme & Individualisme \\
\hline
\end{tabular}

Warga suatu masyarakat pedesaan mempunyai hubungan yang lebih erat dan lebih mendalam ketimbang hubungan mereka dengan warga masyarakat pedesaan lainnya. Sistem kehidupan biasanya berkelompok atas dasar sistem kekeluargaan (Soekanto, 1994). Selanjutnya Pudjiwati (1985), menjelaskan ciri-ciri relasi sosial yang ada di desa itu, adalah pertama-tama, hubungan kekerabatan. Sistem kekerabatan dan kelompok kekerabatan masih memegang peranan penting. Penduduk masyarakat pedesaan pada umumnya hidup dari pertanian, walaupun terlihat adanya tukang kayu, tukang genteng dan bata, tukang membuat gula, akan tetapi inti pekerjaan penduduk adalah pertanian. Pekerjaan-pekerjaan di samping pertanian, hanya merupakan pekerjaan sambilan saja.

\section{Pemberdayaan Masyarakat}

hubungan antara pribadi tanpa ketegasan yang dinyatakan eksplisit. Masyarakat desa menggunakan bahasa tidak langsung, untuk menunjukkan sesuatu. Dari uraian tersebut (pendapat Talcott Parson) dapat terlihat pada desa-desa yang masih murni masyarakatnya tanpa pengaruh dari luar.

Perbedaan ciri antara perkotaan dan pedesaan dapat diungkapkan secara singkat menurut Poplin (1972) sebagai berikut:

\begin{abstract}
Menurut
Adisasmita pemberdayaan masyarakat adalah upaya pemanfaatan dan pengelolaan sumber daya masyarakat pedesaan secara efektif dan efisien, baik dari aspek masukan (SDM, dana, peralatan/sarana, data, rencana, dan teknologi), dari aspek proses (pelaksanaan, monitoring, dan pengawasan), dari aspek keluaran atau output (pencapaian sasaran, efektivitas dan efisiensi).
\end{abstract}

\section{Pembangunan Desa}

Pembangunan merupakan proses multi dimensional yang menyangkut perubahan-perubahan yang penting dalam suatu struktur, sistem sosial ekonomi, sikap masyarakat dan lembaga-lembaga nasional dan akselerasi pertumbuhan ekonomi, pengangguran kesenjangan dan pemberantasan kemiskinan absolut (Todaro,1977). Pengertian tersebut mengisyaratkan bahwa pembangunan 
berarti proses menuju perubahanperubahan yang dimaksudkan untuk memperbaiki kualitas kehidupan masyarakat itu sendiri. Adapun Ginanjar Kartasasmita $(1997 ; 9)$ memberikan pengertian yang lebih sederhana tentang pembangunan yaitu: "suatu proses perubahan ke arah yang lebih baik melalui upaya yang dilakukan secara terencana".

Todaro melihat pembangunan sebagai: "proses yang multi dimensional dari struktur masyarakat, perilaku, kelembagaan, perkembangan ekonomi, pengurangan kepincangan, dan penghapusan kemiskinan absolut dari masyarakat". Tiga nilai yang menjadi tujuan pembangunan adalah: (1) Live sustainance atau terpenuhinya kebutuhan dasar manusia berupa sandang, pangan papan, kesehatan, dan perlindungan dari ancaman, (2) self esteem, kemampuan untuk menjadi diri sendiri, (3) freedom for survitude, yaitu kemampuan untuk memilih secara bebas.

Pembangunan masyarakat desa menurut Tjokrowinoto (1999:35) dapat dilakukan berdasarkan 3 azas, diantaranya: (1) azas pembangunan integral, (2) azas kekuatan sendiri, (3) azas pemufakatan bersama. Azas pembangunan integral ialah pembangunan yang seimbang dari semua segi masyarakat desa. Azas kekuatan sendiri adalah tiap-tiap usaha pertama-tama harus

berdasarkan kekuatan sendiri, azas pemufakatan bersama ialah pembangunan harus dilaksanakan secara benar untuk menjadi kebutuhan masyarakat desa dan putusan untuk melaksanakan proyek bukan atas prioritas atasan tetapi merupakan keputusan bersama anggota masyarakat desa. Disamping itu strategi desa yang telah dikembangkan antara lain pendekatan dari atas (top down), pendekatan dari bawah (bottom up) dan pendekatan pengelolaan mandiri oleh masyarakat desa (community base management). Pendekatan 'top down' dilaksanakan berdasarkan jalan pikiran bahwa masyarakat desa adalah pihak yang bodoh dan belum dapat memikirkan serta mengerjakan apa yang baik untuk mereka. Jadi semua segi kehidupan dirancang dan diturunkan dari pemerintahan. Pendekatan 'bottom up' dilaksanakan dengan asumsi bahwa masyarakat desa telah memiliki kemampuan untuk memikirkan dan mengerjakan kebutuhannya sendiri dan pemerintah hanya turut serta dalam sistem administrasinya. Pendekatan 'community base management' sebenarnya bukan gagasan baru namun muncul dan digali dari masyarakat setempat yang diangkat dari praktek masyarakat tradisional dalam mengelola sumber daya alam untuk kesejahteraan ekonomi bersama dalam desa tanpa campur tangan pemerintah.

\section{PEMBAHASAN}

\section{Gambaran Umum Desa Namo Bintang}

Desa Namo Bintang merupakan salah satu desa yang terdapat di Kecamatan Pancur Batu, Kabupaten Deli Serdang. Desa Namo Bintang memiliki luas 495,2 hektare, yang terdiri dari 50 hektare daerah pemukiman, 35 hektare daerah pertanian sawah, 200 hektare daerah perladangan dan 150 hektare daerah perkebunan serta 60,2 hektare untuk fasilitas umum dan lain-lain. Desa Namo Bintang memiliki 5 dusun dengan 1577 jumlah KK. Desa Namo Bintang telah melakukan program-program kegiatan dalam mengembangkan daerah mereka, seperti ekonomi masyarakat, pendidikan, kesehatan, kedaulatan politik, dan keamanan ketertiban termasuk juga dalam penyelenggaraan program pembangunan desa seperti P2KP yang diberikan pemerintah. Desa ini terdiri dari 5 (lima) dusun, yaitu:

Dusun I : Desa Namo Bintang dan Namo Bintang Kuta 
Dusun II : Desa Sumberingen dan Kloni IV

Dusun III : Desa Rumah Mbacang dan Ujung Jawi

Dusun IV : Desa Simpang Gardu dan Simpang Kongsi

Dusun V : Desa GRT Tahap I dan GRT Tahap II.

Secara administratif Desa Namo Bintang berbatasan dengan Kota Medan di sebelah Utara, Desa Namo Simpur kecamatan Pancur Batu di sebelah Selatan, Desa Durin Tonggal kecamtan Pancur Batu di sebelah timur dan berbatasan dengan Desa Baru kecamatan Pancur Batu di sebelah Barat. Desa Namo Bintang mempunyai dua iklim yaitu musim kemarau dan musin penghujan, dimana kedua iklim tersebut dipengaruhi oleh angin laut dan angin pegunungan yang merupakan salah satu faktor pendukung dalam kesuburan tanah. Sarana Lembaga Ketahanan Masyarakat Desa Namo Bintang yang bertujuan untuk mengembangkan aspek-aspek kehidupan masing-masing seksi jumahnya relative kecil. Sarana-sarna LKMD yang sudah tersedia antara lain :

- Sarana keagamaan, dengan membentuk satu kelompok remaja mesjid yang diberi nama Himpunan Remaja Mesjid Amal Nahdatul Namo Bintang (HIRMAN) dan satu kelompok pemuda Gereja (PERMATA) GBKP serta Naposo Nauli Bulung Gereja HKBP dan GKPS.

- Sarana Pemuda, dengan membentuk satu kesatuan Karang Taruna Namo Bintang.

- Sarana olahraga, dengan membentuk satu kesatuan olahraga yang memanfaatkan sarana lapangan olahraga volley dan lapangan sepak bola.

- Sarana kesehatan, dengan membangun satu unit Puskesmas pembantu serta satu unit POSYANDU.
- Sarana organisasi sosial dengan membentuk satu kelompok anggota PKK dan delapan anggota Dasawisma.

- Sarana pendidikan di desa Namo Bintang hanya tersedia untuk Sekolah Dasar yaitu Sekolah Dasar Negeri dan Sekolah Dasar Inpres. Umumnya warga masyarakat telah tamat SD melanjutkan sekolah SMP ke ibukota kecamatan Pancur Batu. Demikian juga halnya untuk tingkat SLTA dilanjutkan ke Pancur Batu dimana SLTP dan SLTA telah banyak tersedia baik itu negeri maupun swasta.

Pembangunan Pedesaan dilaksanakan untuk memberdayakan masyarakat miskin di pedesaan. Pembangunan yang dilakukan di Desa Namo Bintang adalah salah satunya Pembangunan Irigasi. Oleh karena itu, program ini harus melibatkan masyarakat dalam pelaksanaannya, dan ada juga yang berperan sebagai motivator. Sejauh ini keterlibatan mereka sudah cukup baik. Namun kelemahannya tidak semua masyarakat di desa ini ikut berpartisipasi dalam pembangunan saluran irigasi. Masalah yang dihadapi Desa Namo Bintang dalam pelaksanaan pembangunan pedesaan ini adalah sebagai berikut:

1. Kurangnya dana terhadap pelaksanaan pembangunan pedesaan

2. Sistem pencairan dana yang berbelit-belit

3. Kurangnya sosialisasi pemerintah kepada masyarakat

4. Pembangunan yang dilaksanakan tidak sesuai dengan kebutuhan masyarakat.

\section{SIMPULAN}

Desa Namo Bintang adalah salah satu desa yang ada di kecamatan Pancur Batu, yang mayoritas penduduknya memiliki pekerjaan dalam bidang pertanian. Desa Namo Bintang 
merupakan salah satu desa yang penduduknya kurang mampu. Hal ini dibuktikan dari mata pencaharian mereka. Dengan keadaan ini pemerintah memberikan bantuan dalam program P2KP untuk mensejahterakan dan memberdayakan masyarakat.

Program Peningkatan Kualitas Permukiman (P2KP) di Pedesaan Namo Bintang telah banyak dilaksanakan, salah satunya adalah saluran irigasi. Dalam pelaksanaan Program Peningkatan Kualitas Permukiman (P2KP) di Pedesaan ini, tidak terlepas dari kendala-kendala . seperti kurangnya dana, sistem pencairan dana yang berbelit-belit, serta adanya sebagian masyarakat yang tidak peduli terhadap program tersebut.

$$
\text { Untuk itu upaya dalam }
$$
menanggulangi masalah yang terjadi dapat dilakukan dengan melakukan tinaju lokasi oleh pemerintah. Selain itu, maka seharusnya anggaran dana untuk Program Peningkatan Kualitas Permukiman (P2KP) di Pedesaan tersebut langsung diberi secara keseluruhan tanpa harus bertahap .

Golongan orang-orang tua pada masyarakat pedesaan umumnya memegang peranan penting. Orang akan selalu meminta nasihat kepada mereka apabila ada kesulitan-kesulitan yang dihadapi. Nimpoeno (1992) menyatakan bahwa di daerah pedesaan kekuasaankekuasaan pada umumnya terpusat pada individu seorang kiyai, ajengan, lurah dan sebagainya.

\section{DAFTAR PUSTAKA}

Abe, Alexander, 2001, Perencanaan daerah memperkuat prakarsa rakyat dalam otonomi daerah, Lapera Pustaka Utama, Yogyakarta.

Abe, Alexander, 2002, Perencanaan Daerah Partisipatif, Penerbit Pondok Edukasi, Solo.
Adi, Isbandi Rukminto, 2001, Pemberdayaan, Pengembangan Masyarakat dan Intervensi Komunitas, Lembaga Penelitian FE-UI, Jakarta.

Budi Puspo, Bahan Ajar Metodologi Penelitian Kualitatif, Universitas Diponegoro, Semarang.

Conyers, Diana, 1994, Perencanaan Sosial di Dunia Ketiga: Suatu Pengantar, Gadjah Mada University Press, Yogyakarta.

NurwiMayasri, 2005, Penjaringan Aspirasi Masyarakat dalam Perencanaan Pembangunan Daerah di Provinsi Jawa Tengah, (Studi Optimalisasi Fungsi DPRD), Tesis, Magister Administrasi Publik. Universitas Diponegoro, Semarang.

Hasibuan, Malayu, S.P.Drs, 1993, Manajemen: Dasar, Pengertian dan Masalah, CV. Haju Masagung, Jakarta.

Kunarjo, 2002, Perencanaan dan Pengendalian Program Pembangunan, Universitas Indonesia Press, Jakarta.

Kartasasmita, Ginanjar, 1997, Administrasi Pembangunan, LP3ES, Jakarta.

Moleong, Lexy, 2001, Metodologi Penelitian Kualitatif , PT. Remaja Rosada Karya, Bandung.

Mubiyarto, 1984, Pembangunan Pedesaan, P3PK UGM, Yogyakarta.

Mikkelsen, Britha, 2006, Metode Penelitian Partisipatoris dan Upaya-upaya Pemberdayaan, Yayasan Obor Indonesia, Jakarta.

Michael, Todaro, 1977, Pembangunan ekonomi di dunia Ketiga, Erlangga, Jakarta.

Muhadjir, H. Noeng, 2000, Metodologi Penelitian Kualitatif, Rakesarasin, Yogyakarta.

Milles, MB \& Hubberman, AM, (1992) Analisis Data Kualitatif , Terjemahan oleh Tjetjep 
Rohidi dan mulyarto, UI Percetakan, Jakarta.

Moelyarto, Tjokrowinoto, 1999, Restrukturisasi Ekonomi dan Birokrasi, Kreasi Wacana, Yogyakarta.

Nasution, 1992, Metode Penelitian Naturalistik - Kualitatif, Tarsito, Bandung.

Nazir, Muhamad, 1983, Metode Penelitian, Ghalia Indonesia, Jakarta.

Riyadi dan Bratakusumah, D.S, 2004, Perencanaan Pembangunan Daerah, PT. Gramedia Pustaka Utama, Jakarta.

ReksoPutranto, Soemadi, 1992, Manajemen Proyek Pemberdayaan, Lembaga Penerbitan FE-UI, Jakarta.

Siagian, Sondang P, 1994, Administrasi Pembangunan, Gunung Agung, Jakarta.

Singarimbun, Masri dan sofyan Effendi, 1986, Metode Penelitian Survey, Suntingan LP3ES, Jakarta.

Sugiyono, 2008. Memahami Penelitian Kualitatif, Jakarta.

Soemarmo, 2005, Analisis Pelaksanaan Pendekatan Partisipatif Pada Proses Perencanaan Pembangunan Di Kota Semarang (Studi Kasus Pelaksanaan Penjaringan Aspirasi Masyarakat Di Kecamatan Banyumanik), Tesis, Magister Administrasi
Publik, Universitas

Diponegoro, Semarang.

Tjokroamidjojo, Bintoro, 1995, Manajemen Pembangunan, Gunung Agung, Jakarta.

Wijaya, Rina, 2001, Forum Pengambilan Keputusan dalam Proses Perencanaan Pembangunan di Era Otonomi Daerah (Studi Kasus Di Kelurahan Jebres Kecamatan Jebres Kota Surakaarta), Tesis, Magister Perencanaan Kota dan Daerah, Universitas Gajah Mada, Yogyakarta.

Undang-undang No. 25 Tahun 2004 tentang Sistem perencanaan pembangunan Nasional.

Undang-undang No. 32 Tahun 2004 Tentang Otonomi Daerah.

Surat Edaran Bersama Mentri Negara Perencanaan Pembangunan Nasional/Kepala Bappenas dan Mentri dalam Negeri Nomor

0295/M.PPN/1/2005 dan 050/166/sj tertanggal 20 Januari 2005 diatur petunjuk teknis Musrenbang.

Peraturan Bupati No. 11 Tahun 2007 Tentang Tata Cara Penyusunan, Penetapan, dan Pelaporan Rencana Kerja Pemerintah Kabupaten Sukabumi.

Rencana Pembangunan Jangka Menengah (RPJMD) Daerah Kabupaten Sukabumi Tahun 20062010 